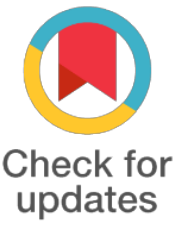

${ }^{*}$ For correspondence:

pypuah@hotmail.com

Competing interests: The authors declare that no competing interests exist.

Received: 2017-04-30

Accepted: 2017-06-03

Published: 2017-09-05

Copyright The Author(s) 2017. This article is published with open access by BioMedPress (BMP).

This article is distributed under the terms of the Creative Commons Attribution License (CC-BY 4.0) which permits any use, distribution, and reproduction in any medium, provided the original author(s) and the source are credited.

\section{Preparation of graphene oxide/oligopeptides composite for promoting mesenchymal stem cell proliferation}

\author{
Perng Yang Puah, Pc Lee, Py Moh, Se How \\ Faculty Science and Natural Resources, University Malaysia Sabah, Jalan UMS, Kota Kinabalu, \\ Sabah 88400, Malaysia
}

\begin{abstract}
Human mesenchymal stem cells (hMSCs) treatments are being tested clinically for a range of disorders. However, ex vivo expansion of hMSCs is still depending on human or animal source extracellular matrix (ECM) molecules. These ECM molecules are expensive to manufacture, have limited scalability and high batch-to-batch variability. Surface modification techniques have been instrumental in the development of scaffolds that promote cell-surface interactions. In this study, the surface of graphene oxide (GO) was modified in order to promote the attachment and proliferation of mesenchymal stem cells (hMSCS). YIGSR, WYQNMIR, IKVAV and QHREDGS peptide sequences derived from ECM adhesion peptides were combined alternatively to form oligopeptides and each oligopeptide was attached to GO through $\pi-\pi$ and electrostatic interactions. The presence of peptide bond in the GO/peptide composites were confirmed by using modified Lowry method. The GO/Peptide-IKVAV composite showed increase proliferation rate and better attachment of hMSCs at day 1 as compared to GO substrate. In addition, the GO/Peptide-IKVAV composite proved to be a suitable environment for the time-dependent viability of hMSCs. The data obtained here collectively demonstrates that the GO/PeptideIKVAV composite is a potential substrate for the adhesion and proliferation of hMSCs.
\end{abstract}

\section{Keywords}

human mesenchymal stem cells, graphene oxide, oligopeptide, proliferation

Funding

Trans Disciplinary Research Grant Scheme

\title{
References
}

